\title{
J. D. Y. PEEL: A TRIBUTE
}

I was shocked when a colleague sent me a text message to inform me about J. D. Y. Peel's demise. I just missed seeing him when he came to Nigeria to give Chief Olanihun Ajayi's ninetieth birthday commemorative lecture a few months before.

John was a highly regarded scholar and friend. My first interaction with him was when he was still at the University of Ife, later Obafemi Awolowo University (OAU), where I quickly recognized him as a kindred spirit with his emphasis on the need to understand the social and cultural factors undergirding significant developments in African history. Later, I read his famous work, Ijesas and Nigerians: the incorporation of a Yoruba kingdom, 1890s-1970s, published in 1983 by Cambridge University Press. It is a social history of the Ijesa kingdom's integration into Nigeria from the period of the British colonial administration to our independence. It examined the changes in politics, economic and ethnic identity that occurred as a result of these historical developments.

Its publication occurred during the period of the birth of the Ijesa Cultural Foundation; this was a society founded by a few of us with the aim of sensitizing the Ijesa to the significance of their history and culture. Unfortunately, this book went out of print before many Ijesa could have access to it. We felt that its publication in Nigeria would provide a launching pad for this foundation. John readily gave us the copyright and agreed to donate the proceeds to the development of Ijesaland. We were able to publish a Nigerian edition in 2002; it was launched with a great deal of fanfare, with the Owa Obokun of Ijesa kingdom and a large host of Ijesa dignitaries from all over Nigeria in attendance. It became a highly prized book in their private libraries.

Apart from this work on the Ijesa kingdom, scholars in the field of religious studies will certainly highlight his contribution to the discussion of religion and religious practices, an area in which he also made an impact. I once had the opportunity of discussing with him the proliferation of churches in Ibadan and their effect on our public life.

Peel was not only a scholar; he was also a humane person, a good example of the social anthropologist who gets the best out of his research by being at home in the field and by his unassuming interaction with friends and colleagues. Within this context one must mention the J. F. Ade-Ajayi connection. Emeritus Professor Ajayi, a distinguished scholar of history and former member and chairman of the Council of the International African Institute, who himself passed away recently, provided in his home in Ibadan, with his charming wife as hostess, a most welcome meeting place for scholars from abroad and from within Nigeria. Peel was often in his element here, discussing local politics, developments in the field of scholarship, and so on. It also gave him the opportunity to try out his knowledge of the Yoruba language. He found himself more at home in Ibadan than elsewhere in Nigeria.

Only recently, when he came to give Olanihun Ajayi's ninetieth birthday lecture in 2015, he still preferred to spend most of his time in the J. F. Ajayi household in Ibadan, and he used the opportunity to see some of us. Ironically, Peel himself put 
together J. F. Ajayi's obituaries. ${ }^{1}$ My family will certainly miss this man whom some of us had got to know, but we pray that his soul may rest in peace.

BOLANLE AWE

Bolanle AwE is a Fellow of the Nigerian Academy of Letters, retired Professor of History and former Director of the Institute of African Studies of the University of Ibadan.

${ }^{1}$ J. D. Y. Peel (2015) 'J. F. Ade Ajayi: a memorial', Africa 85 (4): 745-9. 